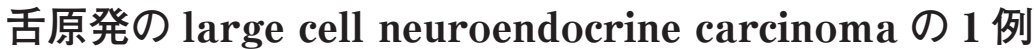

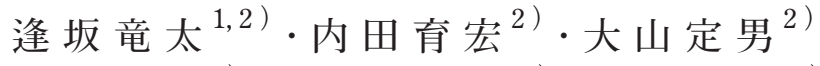 \\ 宮下英高 ${ }^{2}$ ・河合繁夫 ${ }^{3)}$. 柴原孝彦 ${ }^{1)}$
}

\section{A case of large cell neuroendocrine carcinoma of the tongue}

\author{
OSAKA Ryuta $^{1,2)} \cdot$ UCHIDA Ikuhiro $^{2)} \cdot$ OYAMA Sadao $^{2)}$ \\ MIYASHITA Hidetaka $^{2)} \cdot$ KAWAI Shigeo $^{3)} \cdot$ SHIBAHARA Takahiko $^{1)}$
}

\begin{abstract}
Large cell neuroendocrine carcinomas (LCNEC) are relatively rare tumors that arise in various organs. We report a case of primary LCNEC of the tongue.

A 60-year-old man was referred to our department because of impaired swallowing function due to pain while eating, as well as an ulcer on the left side of the tongue. Squamous cell carcinoma was suspected on biopsy. A whole-body examination showed no evidence of metastasis. Therefore, the patient was given a clinical diagnosis of squamous cell carcinoma of the left side of the tongue suspected (cT4aN2bM0: Stage IVa). After preoperative chemotherapy, we performed a tracheostomy, bilateral neck dissection, complete removal of the tongue, and reconstructive surgery using a rectus abdominis free flap, with the patient under general anesthesia.

Histologically, the tumor was composed of solid nests of atypical large cells. Necrosis was remarkable. Tumor nests showed peripheral palisading and rosette formation. Immunohistochemically, the cancer cells were positive for chromogranin A and synaptophysin. We diagnosed this tumor as LCNEC, based on the criteria established for pulmonary tumors. The patient is alive without recurrence or metastasis 55 months after surgery.

Since LCNEC is exceptionally rare in the head and neck region, especially in the oral cavity, the prognosis was unclear, and treatment has not been established. Hence, studies of further cases are required to establish adequate treatment for LCNEC of the head and neck region.
\end{abstract}

Key words: oral cancer (口腔癌)， large cell neuroendocrine carcinoma (大細胞神経内分泌癌)

緒 言

Neuroendocrine tumor（以下；NET）はさまざまな臓器 に発生するまれな腫瘍で, 肺においては, carcinoid tumor, atypical carcinoid tumor, small cell carcinoma (以下 ; SCC) および large cell neuroendocrine carcinoma (以下 ; LCNEC) に分類されている ${ }^{1 \sim 2)}$.

頭頸部領域, とくに口腔原発の NET の報告例は少ない ${ }^{3}$ ). 今回我々は，きわめてまれな舌原発の LCNECの 1 例を経 験したので報告する.
症

例

患 者：60 歳, 男性.

初 診: 2010 年 4 月中旬.

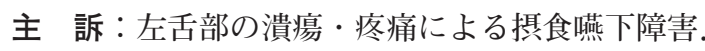

既往歴：1990 年, 肺結核。 2010 年, 2 型糖尿病.

家族歴：特記事項なし。

現病歴：2008 年左舌部に潰瘍を認め, 他施設柬科口腔 外科を受診し精査勧められるも放置した。 2010 年 2 月左
1) 東京柬科大学口腔外科学講座

(主任：柴原孝彦教授)

2) がん・感染症センター都立駒込病院茵科口腔外科 (主任：茂木伸夫部長)

3) 国立国際医療研究センター病院中央検査部臨床病理室 (主任：猪狩 亨医長)

${ }^{1)}$ Department of Oral and Maxillofacial Surgery, Tokyo Dental College (Chief: Prof. SHIBAHARA Takahiko)
${ }^{2)}$ Department of Dentistry/Oral Surgery, Tokyo Metropolitan Cancer and Infectious Disease Center Komagome Hospital (Chief: Dr. MOTEGI Nobuo)

${ }^{3)}$ National Center for Global Health and Medicine, Pathology Division of Clinical Laboratory (Chief: Dr. IKARI Toru) 受付日：2012 年 4 月 2 日 採択日：2015年 1 月 27 日 
舌部の潰瘍・疼痛増大による摂食困難を自覚し, 2010 年 4 月中旬に他施設歯科口腔外科より都立駒込病院柬科口腔外 科を紹介され，受診した。

\section{現 症:}

全身所見; 体格中等度, 栄養状態不良, その他特記事項 なし.

口腔外所見 ; 両側顎下部に最大径 $10 \mathrm{~mm}$ 大，やや腫大し 丸みを帯びたリンパ節を認め，とくに患側に弾性硬の固着 性リンパ節を触知した。

口腔内所見; 左舌縁部から舌全体に及ぶ，弾性硬 $80 \times$ $40 \mathrm{~mm}$ 大の壊死・潰瘍伴う，一部易出血性の腫瘍性病変を 認めた (写真 1$)$.

\section{画像所見 :}

CT 所見; 左舌縁部から舌全体に及ぶ $80 \times 33 \mathrm{~mm}$ 大 の淡く造影された不整な腫瘤を認め, 両側顎下部に最大 $13 \mathrm{~mm}$ 大の腫大リンパ節が散見され, リンパ節転移が疑わ れた。同時に施行した胸腹部造影 CTにて胸腹部および骨 盤内の藏器に腫瘤性病変は認めなかった。頸部リンパ節以 外に有意な腫大リンパ節を認めなかった (写真 $2 \mathrm{~A}, \mathrm{~B})$.

MRI 所見 ; 左舌縁部から舌体部, 舌尖部, さらに口底 に浸潤する $50 \times 50 \times 50 \mathrm{~mm}$ 大の不整形な腫瘤を認め， $\mathrm{T} 1$ 低信号・T2 高信号, 造影後には不均一ながら強い増強 効果を認めた.

Te シンチグラフィー所見；骨転移を疑う異常集積は認 めなかった。

上部消化管内視鏡所見 ; 咽喉頭 - 食道 $\cdot$ 胃 ·十二指腸に 異常所見は認めなかった。

臨床診断：左側舌扁平上皮癌疑い (cT4aN2bM0: StageI$\mathrm{Va})$.

処置および経過：2010 年 4 月下旬，摂食困難による低栄 養状態の改善および精査目的に入院した。入院後に施行し た生検にて扁平上皮癌疑いと診断された。その後，neoadjuvant chemotherapy (以下 ; NAC) として 5-FU (1,000mg/ $\mathrm{m}^{2} /$ day1-5) + CDDP (13mg/ $\mathrm{m}^{2} /$ day1-5) による FP 療法を 1 コース施行し, 左側舌縁部腫瘍性病変の著明な縮小を認 めた. 2010 年 6 月, 全身麻酔下に気管切開術・左全頸部 郭清術・副咽頭腔郭清術・舌全摘出術・遊離腹直筋皮弁に よる再建術，健側腫大リンパ節に対して予防的に右顎下部 郭清術を施行した。原発部は下唇を正中離断後, 副咽頭腔 間隙を茎状突起が確認できるところまで郭清し，舌全摘出 術を施行した. 形成外科にて腹部左側より左深下腹壁動静 脈を血管茎とする遊離腹直筋皮弁を採取し，皮弁の咽頭側 縫合後, 皮弁舌部を残存蒾肉部に縫合した。下顎骨正中離 断部をチタンプレートにて固定後, 口唇部まで皮弁を縫 着, 右顔面動脈・外頸静脈にそれぞれの血管を吻合した。 術後, 一過性の創部感染を認めたが抗菌薬投与にて症状改
善し，その後創部治癒は良好であった。

本症例に扔いては都立駒込病院呼吸器外科, 化学療法科 と相談のうえ S-1 $\left(80 \mathrm{mg} / \mathrm{m}^{2} / 4\right.$ weeks $)$, CDDP $(10 \mathrm{mg} /$ day 14, 28) による adjuvant chemotherapy（以下；AC）を 4 コ 一ス施行した。術後 55 か月経過現在, 再発打よび転移認 めず経過良好である。

摘出標本所見：摘出標本は $90 \times 85 \times 45 \mathrm{~mm}$ 大, 左舌尖 部に $48 \times 25 \mathrm{~mm}$ 大の外向性かつ内向性に発育する境界比 較的明睹な白色調充実性腫瘍が存在していた（写真 3).

病理組織学的所見：生検標本では, 明瞭な核小体と粗糙 なクロマチンをもつ好酸性の細胞質を有する多角形から紡 錘形の大型の異型細胞が, 不整形な充実性胞巣を形成ある いは索状構造を示して増殖, 浸潤していた。腫瘍胞巣辺縁 では腫瘍細胞は柵状に配列していた。胞巣内にはときにロ ゼット様構造も認められた。核分裂像が多くみられ（約 30 個 / $10 \mathrm{HPF}$ ），著明な壊死を伴っていた。角化や細胞間橋は 明らかではなく，腺管形成や粘液産生もみられなかった。 また唾液腺型腫瘍の所見もなかった (写真 4A, B). 低分化 扁平上皮癌あるいは basaloid squamous cell carcinoma が考 えられたが, 生検標本では腫瘍の一部しか観察できていな いことから, 扁平上皮癌疑いと診断された。摘出標本では, 腫瘍は生検標本とほほ同様の成分のみから構成され, 角化 を伴う典型的な扁平上皮癌の成分は確認できなかった（写 真 5A， B). また， ロゼット様構造がより明瞭に認められ た (写真 5C). そこで神経内分泌癌の可能性も考慮され免 疫染色を施行したところ, 生検標本, 摘出標本いずれにお いても chromogranin A は多くの腫瘍細胞が陽性で（写真 6A), synaptophysin は一部の腫瘍細胞が陽性を示した（写 真 6B). CD56 は陰性であった。一方, 扁平上皮癌のマー カーである $34 \beta \mathrm{E} 12, \mathrm{CK} 5 / 6, \mathrm{p} 63$ および $\mathrm{p} 40$ はいずれも 少数の腫瘍細胞にのみ陽性であった (写真 $6 \mathrm{C})$. また cytokeratin20（CK20）は腫瘍細胞の細胞質には染まったが，核 周囲のドット状の陽性像は認められなかった (写真 6D). また, 摘出標本では, 腫瘍はところどころで粘膜被覆扁平 上皮と連続していたが腫瘍と粘膜被覆上皮との境界は明瞭 で, 粘膜上皮内に腫瘍性病変は確認できなかった (写真 7). 摘出標本に打いては, 腫瘍細胞は変性像にそしく, ほと んどの腫瘍細胞は viable であったが, 周囲には炎症細胞浸 潤や幼若な線維性間質の増生が認められ, NACの効果が 示唆される所見であった。 また, 郭清されたリンパ節に転 移あるいは転移があったことを疑わせる所見は認められな かった。

病理組織診断:Large cell neuroendocrine carcinoma, state after chemotherapy (pT4aN0M0: Stage IVa). 


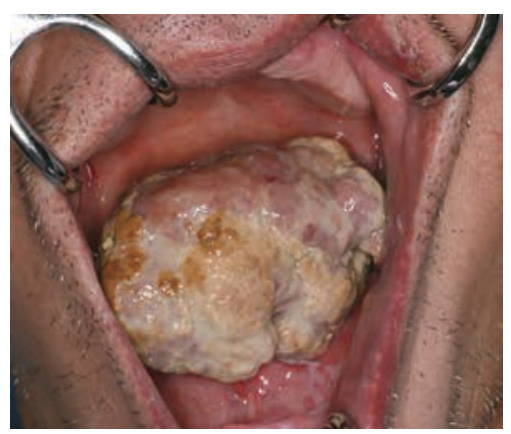

写真 1 初骖時口腔内写真 左舌縁部から舌全体に及ぶ，弾性硬 $80 \times 40 \mathrm{~mm}$ 大の壊死 - 潰瘍伴う，一 部易出血性の腫瘍性病変を認める.

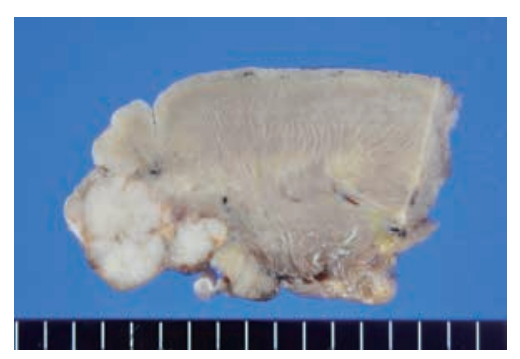

写真 3 摘出標本写真 (矢状方向割面像) $48 \times 25 \mathrm{~mm}$ 大の外向性かつ内向性に 発育する白色調充実性腫瘍が認められ る。
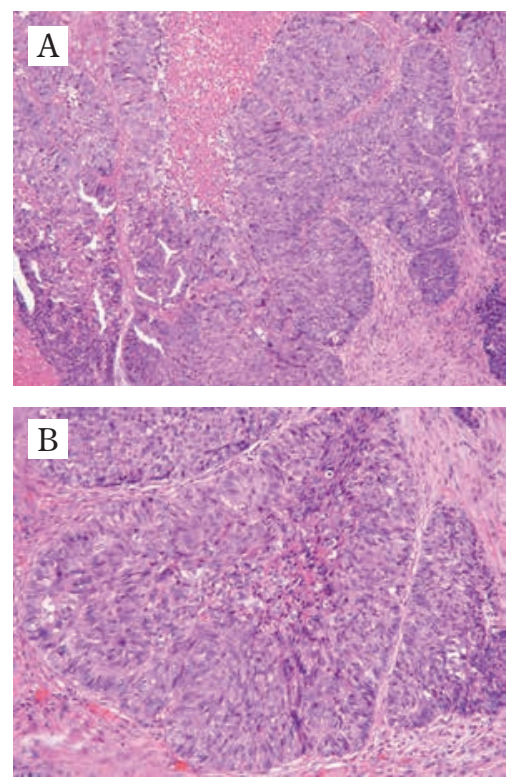

写真 4 生検標本病理組織像

(H-E 染色, A : × 40 B : × 100) 腫瘍細胞は壊死を伴う充実性胞巣を 形成している。胞巣辺縁ではしばしば 腫瘍細胞が柵状に配列している。
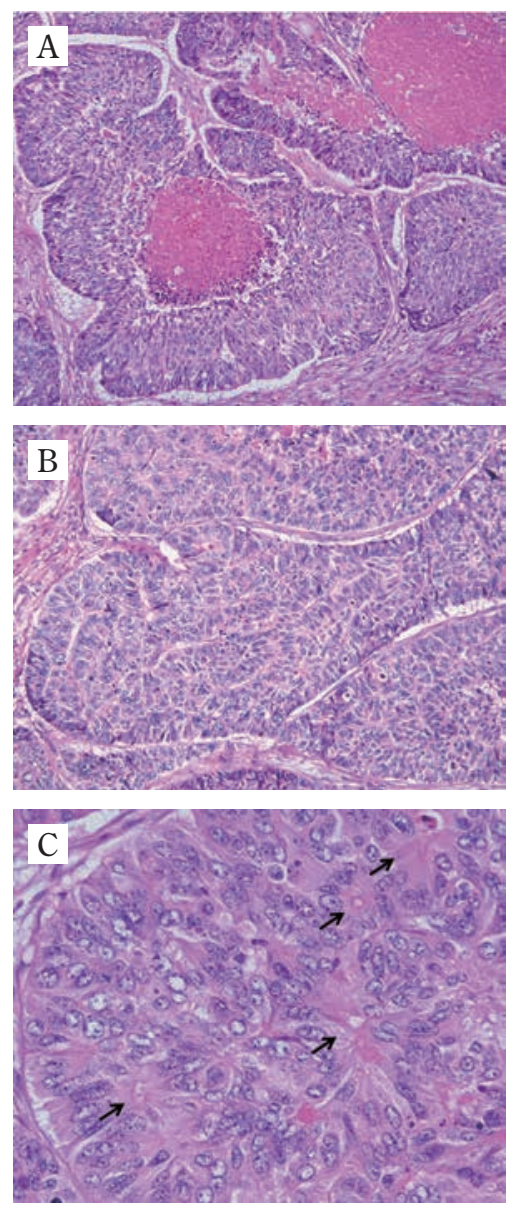

写真 5 摘出標本病理組織像

(H-E 染色, A : $\times 40$

B : × $100 \quad \mathrm{C}: \times 400)$

$\mathrm{A}$ ：生検標本とほぼ同様の組織像.

B：索状構造を示している部分.

$\mathrm{C}$ ：腫瘍細胞は好酸性の細胞質と核小体 明瞭でクロマチン粗糙な核を有して いる. 摘出材料では口ゼット様構造 がより明瞭に認められる $(\rightarrow)$.

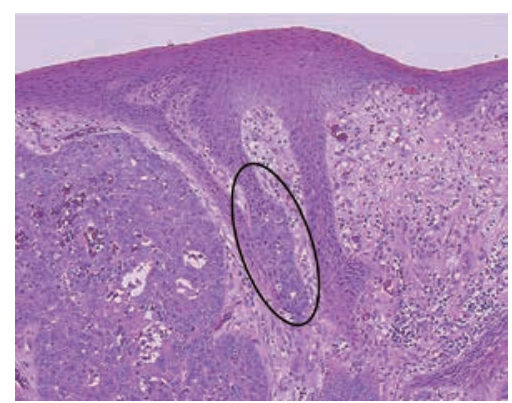

写真 7 摘出標本病理組織像 $(\mathrm{H}-\mathrm{E}$ 染色，×20)

腫瘍は一部で粘膜被覆重層扁平上皮と 連続する（楕円で囲んだ部分）が, 被覆 上皮に腫瘍性病変は認められない。
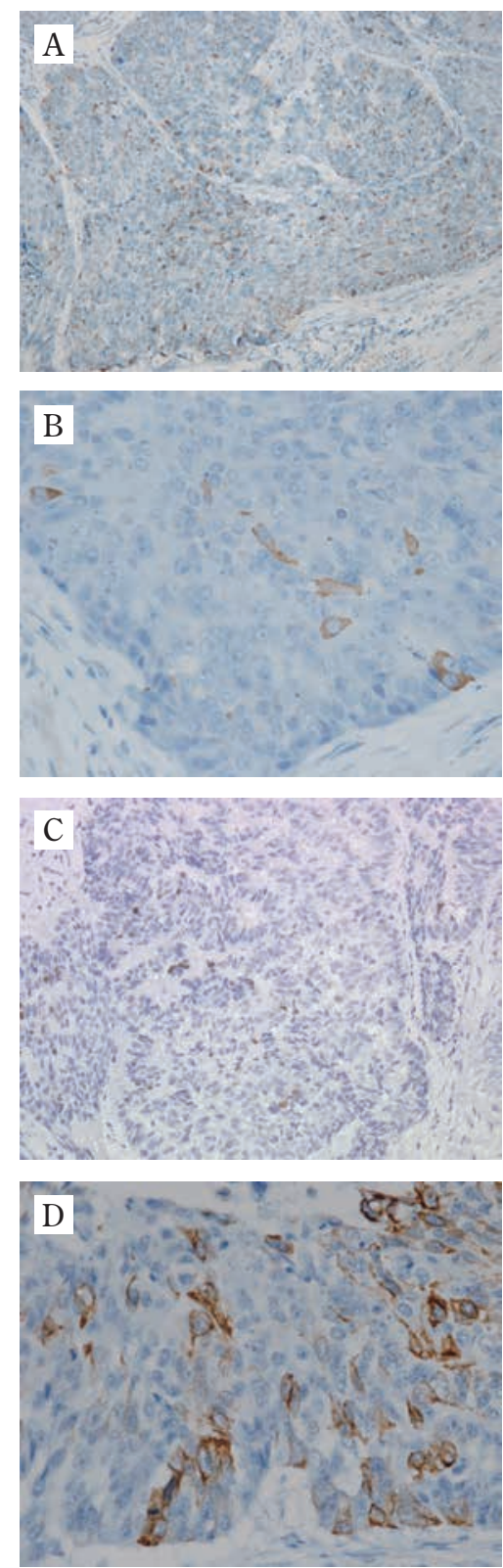

写真 6 摘出標本免疫組織化学染色

( A : Chromogranin A $\times 100$

B : Synaptophysin $\times 400$

C: $\mathrm{p} 63 \times 400$

$\mathrm{D}: \mathrm{CK} 20 \times 400)$

多くの腫瘍細胞が chromogranin A に 陽性で, 一部の腫瘍細胞が synaptophy$\sin$ に陽性を示す。p63 は少数の腫瘍細 胞のみに陽性. CK20 は腫瘍細胞の細胞 質には染まるが，核周囲のドット状の陽 性像は認められない。 

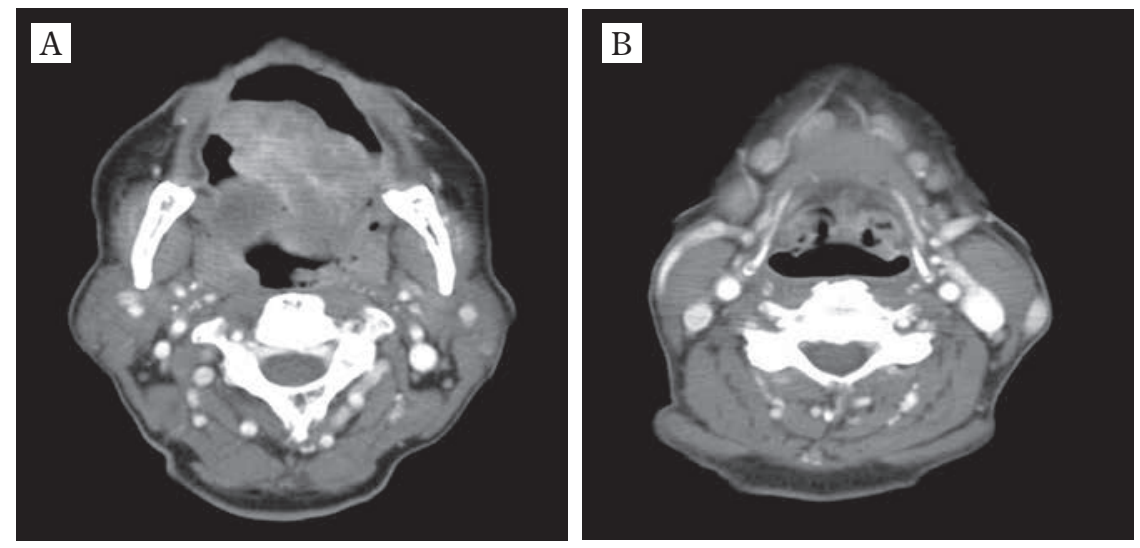

写真 2 術前 (初診時より 1 週後) CT 写真

$\mathrm{A}$ ：左舌部に $80 \times 33 \mathrm{~mm}$ 大の淡く造影された不整な腫瘤を認める.

$\mathrm{B}$ ：両側顎下部に最大 $13 \mathrm{~mm}$ 大の腫大リンパ節が散見される。

表 1 口腔内における LCNEC の報告例

\begin{tabular}{|c|c|c|c|c|c|c|c|c|c|}
\hline 症例 & 報告者 & 報告年 & 性別 & 年齢 & 部位 & cTNM & 治療内容 & 転帰 & \\
\hline 1 & 奥 9) & 2002 & $\mathrm{M}$ & 59 & 下顎歯肉 & T2N2bM0 & $\mathrm{NAC}(\mathrm{PEP}) \rightarrow \mathrm{OPE} \rightarrow \mathrm{AC}(\mathrm{CDDP}+\mathrm{VP}-16)$ & 死亡 (腫瘍死) & $8 \mathrm{M}$ \\
\hline 2 & Kusafuka ${ }^{10)}$ & 2009 & $\mathrm{M}$ & 79 & 舌 & unknown & OPE & 無病生存 & $18 \mathrm{M}$ \\
\hline 3 & Kusafuka ${ }^{11)}$ & 2012 & $\mathrm{M}$ & 61 & 舌 & $\mathrm{T} 2 \mathrm{~N} 2 \mathrm{cM} 0$ & $\mathrm{OPE} \rightarrow \mathrm{AC}$ & 死亡 (他病死) & $35 \mathrm{M}$ \\
\hline 4 & Kusafuka ${ }^{11)}$ & 2012 & $\mathrm{M}$ & 65 & 舌 & T2N0M0 & OPE & 死亡（腫瘍死） & $50 \mathrm{M}$ \\
\hline 5 & 本症例 & 2015 & M & 60 & 舌 & T4N2bM0 & $\mathrm{NAC}(\mathrm{CDDP}+5-\mathrm{FU}) \rightarrow \mathrm{OPE} \rightarrow \mathrm{AC}(\mathrm{S}-1+\mathrm{CDDP})$ & 無病生存 & $55 \mathrm{M}$ \\
\hline
\end{tabular}

\section{考察}

NET はペプチドホルモンないしアミンの産生・分泌あ るいは内分泌顆粒の存在で特徴づけられる腫瘍で, 内分泌 臓器だけではなくさまざまな臓器に発生する。なかでも肺 や消化管は好発臓器である。肺の NET は carcinoid tumor, atypical carcinoid tumor, SCC およびLCNEC に分類され ている ${ }^{1)}$ 。臨床病理学的に carcinoid tumor は低悪性度, atypical carcinoid tumor は中間悪性度, SCC と LCNECは 高悪性度である ${ }^{2)}$ ，膵・消化管の NET は腫瘍の増殖動態 によって NET G1, NET G2, neuroendocrine carcinoma （以下；NEC）に分類されている. NEC はさらに large cell type と small cell type に亜分類されている ${ }^{4 \sim 5)}$. お执むね, NET G1 と NET G2 が肺 NET の carcinoid tumor, atypical carcinoid tumorに相当し, NECの small cell type と large cell type がそれぞれ肺 NET の SCC と LCNEC に相当する.

NET の病理学的特徴は, 形態的に類器官胞巣, 索状胞 巣, 島状胞巣, 胞巣辺縁の柵状配列, リボン状・ロゼット 様構造といった神経内分泌形態を呈し, 免疫組織化学的に は, chromogranin A, synaptophysin, CD56 といった神経
内分泌マーカーを発現していることである ${ }^{2)}$. LCNEC は 未分化な大型細胞から成り，細胞質が比較的豊富で明瞭な 核小体と粗糙なクロマチンをもつ大型核を有し, 腺癌や扁 平上皮癌の特徴を欠いている。

皮膚に発生する NEC は Merkel cell carcinoma（以下； MCC) と呼ばれ，CK20 による免疫染色で核周囲にドット 状の陽性像を示すことが特徴とされる ${ }^{6)}$. 口腔粘膜に発生 した MCC も過去に報告されている7 ${ }^{7}$.

NET の頭頸部領域での発生は比較的少ない $\left.{ }^{3}\right)$. 頭頸部 領域に打ける発生頻度は喉頭が最も多く, 次いで大唾液腺 の報告が多い ${ }^{8)}$. 口腔の NEC はきわめてまれで，そのほ とんどは SCC あるいは MCC の報告例であり ${ }^{6)}, \mathrm{LCNEC}$ の報告例は我々が渉猟する限り, 本症例を含め 5 例のみ であった ${ }^{9 \sim 11)}$ (表 1)。このように口腔の NET はきわめ てまれであることから, 本症例では生検時に LCNEC が 鑑別に挙がらず扁平上皮癌疑いと診断され，摘出標本で 全体像を観察することでLCNEC と診断されるに至った. Kusafuka らは, 過去に低分化扁平上皮癌あるいは basaloid squamous cell carcinoma と診断された頭頸部癌手術例 97 
例を見直したところ，8例（約 $8 \% ）$ がLCNECであった と報告しており，形態学的に basaloid squamous cell carcinoma との鑑別がとくに難しいことを指摘している ${ }^{11)}$.

舌の LCNEC を診断するにあたり, 肺等の他臓器からの 転移を除外することが必要である。今回，我々はCT等の 画像検査，上部消化管内視鏡にて全身検索を行い，舌以外 の臓器に腫瘍性病変を認めなかったことから, 舌原発の LCNEC と診断した。 また，その起源としては口腔粘膜上 皮あるいは舌小唾液腺由来が考えられるが，いずれかの確 定はできなかった。

肺の LCNEC に対する治療は従来，他の非小細胞癌と同 様に外科的切除が選択されてきたが, Asamura らが行った 10 施設 318 例の症例解析シリーズ ${ }^{12)}$ において, 外科治療 単独では十分な制御は行えず, SCCにおける化学療法・放 射線療法などの補助療法を含む集学的治療戦略の確立が重 要であることが明らかとなった。しかし，現在 LCNECに 対する化学療法の有効性に関する知見は限られており，少 数ではあるが症例の後ろ向き研究による CDDPを含む化 学療法の奏効率が $63.2 \%$ などのデータがあるだけにすぎな い13)。今回の症例では, NACとして施行した FP 療法に て左舌部の腫瘍性病変が顕著に縮小した。NAC施行後に 行った手術により，腫瘍は完全に切除されており，現在ま で再発打よび転移は認められていない. LCNECの 5 年生 存率は $40.3 \%$ と, SCC の $35.7 \%$ に敵する切除予後不良で あるとの報告 ${ }^{12)} も$ もり, 本症例に打いても $\mathrm{AC}$ を施行し た。しかし，舌の LCNEC はきわめてまれな腫瘍であるた め, ACの有用性や最適薬剤についての検討が全く行われ ておらず，さらに肺 LCNEC との類似性についても不明で あることから，頭頸部領域における症例の蓄積と治療指針 の作成が今後の課題であると考えられる。

\section{結語}

今回我々は舌原発の LCNEC の 1 例を経験したので報告 した.

謝辞

稿を終えるにあたり，病理組織学的診断において御多忙の 中御指導くださいました, 東京柬科大学市川総合病院臨床検 査科病理 田中陽一先生に厚く御礼申し上げます.

本論文の要旨は第 56 回 (社) 日本口腔外科学会総会・学術 大会 (2011年 10 月, 大阪) で発表した.

本論文に関して，開示すべき利益相反状態はない.

\section{引用文献}

1) Brambilla E, Pugatch B, et al : Large cell carcinoma. In Travis WD, Brambilla E, eds ; WHO Classification of Tumours, Pathology and Genetics Tumours of the lung, pleura, thymus and heart. IARC Press, Lyon, 2004, p. 45-50.

2 ) Travis WD, Linnoila RI, et al : Neuroendocrine tumors of the lung with proposed criteria for largecell neuroendocrine carcinoma. An ultrastructural, immunohistochemical, and flow cytometric study of 35 cases. Am J Surg Pathol 15: 529-53, 1991.

3 ) Kusafuka K, Ferlito A, et al : Large cell neuroendocrine carcinoma of the head and neck. Oral Oncol 48: 211-215, 2012.

4 ) Rindi G, Arnold R, et al : Nomenclature and classification of neuroendocrine neoplasms of the digestive system. WHO Classification of Tumours of the Digesstive System, IARC Press, Lyon, 2010, p13-14.

5 ) Klöppel G, Rindi G, et al : The ENETS and AJCC/ UICC TNM classifications of the neuroendocrine tumors of the gastrointestinal tract and the pancreas: a statement. Vichows Arch 456: 595-597, 2010.

6 ) James S, Lewis Jr, et al : Oral cavity neuroendocrine carcinoma: a comparison study with cutaneous Merkel cell carcinoma and other mucosal head and neck neuroendocrine carcinomas. Oral Surg Oral Med Oral Pathol Oral Radiol Endod 110: 209-217, 2010.

7 ) Sue S. Yom, David I, et al : Merkel cell carcinoma of the tongue and head and neck oral mucosal sites. Oral Surg Oral Med Oral Pathol Oral Radiol Endod 101: 761-768, 2006.

8) Perez-Ordonez B : Neuroendocrine tumours. In Barnes L, Eveson JW, eds ; WHO Classification of Tumours, Pathology and Genetics Head and Neck Tumours. IARC Press, Lyon, 2005, p26-27.

9 ) 奥 尚久, 梅田正博, 他：巣状に扁平上皮癌への分 化を伴った下顎蒾肉原発複合型大細胞神経内分泌癌 の 1 例. 日口外誌 48: 12-15, 2002.

10) Kusafuka K, Asano R, et al : Large cell neuroendocrine carcinoma of the tongue base: case report of an unusual location with immunohistochemical analysis. Int J Oral Maxillofac Surg 38: 296-299, 2009.

11) Kusafuka K, Abe M, et al : Mucosal large cell neuroendocrine carcinoma of the head and neck regions in Japanese patients: a distinct clinicopathological entity. J Clin Pathol 65: 704-709, 2012.

12) Asamura H, Kameya $T$, et al : Neuroendocrine neoplasms of the lung: a prognostic spectrum. J clin Oncol 24: 70-76, 2006.

13) Yamazaki S, Sekine I, et al : Clinical responses of large cell neuroendocrine carcinoma of the lung to cisplatin-based chemotherapy. Lung cancer 49: 217223, 2005. 